\title{
PENDIDIKAN KARAKTER BERBASIS IMAN DAN TAQWA TERHADAP PESERTA DIDIK
}

\author{
Muchlinarwati \\ STAI Nusantara Banda Aceh \\ ibuw50466@gmail.com \\ Abstrak
}

Pendidikan karakter telah menjadi polemik di berbagai Negara. Pandangan pro dan kontra mewarnai diskursus pendidikan karakter. Pendidikan karakter merupakan bagian dari esensial yang menjadi tugas sekolah, tetapi selama ini kurang perhatian. Pendidikan karakter diartikan sebagai the deliberate us of all demision of school life to foster optimal character development (usaha secara sengaja dari seluruh dimensi kehidupan sekolah untuk membantu pengembangan karakter dengan optimal). Hal ini berarti bahwa untuk mendukung perkembangan karakter peserta didik harus melibatkan seluruh komponen di sekolah baik dari aspek isi kurikulum (the content of the curriculum), prose pembelajaran (the procces of instruction), kualitas hubungan (the quality of relationships), penangganan mata pelajaran (the handling of discipline), pelaksanaan aktivitas ko-kurikuler, serta etos seluruh lingkungan sekolah. Islam adalah ajaran Allah swt kepada umat manusia melalui rasul-Nya, mulai dari nabi Adam as sampai nabi Muhammad saw. Pada generasi nabi Muhammad ajaran itu ada di dalam Alquran. Itu sebabnya, Allah swt memosisikan A-Qur'an sebagai petunjuk bagi umat manusia dan nabi Muhammad saw diposisikan Allah sebagai model orang yang ideal karena ia dianggap oleh Allah sebagai pribadi yang memiliki karakter paripurna (insan kamil).

Kata kunci: pendidikan karakter, iman, taqwa, peserta didik

\section{Abstract}

Character education has become a plemic in various countrie. Views of the pros and cons coloring the character education discourse. Character education is an essential part of school work, but so farhas been lacking attention. Character education is defined as the deliberate us of all demision of school life to foster optimal character development. This means that to support the development of student character must involve all components in the school both from the aspect of curriculum content, the procces of instruction, the quality of relationships, the handling of discipline, implementation of co-curricular activities and ethos throughout the school environment. Islam is the teaching of Allah swt to manind through his messenger, from Adam as to the prophet Muhammad saw. In the generation of prophets Muhammad saw the teaching is in the Al-Qur'an. That is why Allah swt positioned the Al-Qur'an as a guide for mankid and the prophet Muhammad saw in the position of Allah swt as an ideal model because he is considered by Allah swt as a person who has a perfect character( insan kamil).

\section{PENDAHULUAN}

Pendidikan merupakan upaya sadar dan terencana yang dilakukan oleh pendidik untuk mengembangkan segenap potensi peserta didiknya secara optimal. Potensi ini mencakup potensi jasmani dan rohani sehingga melalui pendidikan seorang peserta didik dapat mengoptimalkan pertumbuhan fisiknya agar memiliki kesiapan untuk melakukan tugas-tugas perkembangannya dan dapat mengoptimalkan 
perkembangan rohaninya agar dengan totalitas pertumbuhan fisik dan perkembangan psikisnya secara serasi dan harmoni, dia dapat menjalankan tugas hidupnya dalam seluruh aspeknya, baik sebagai anggota masyarakat, sebagai individu maupun sebagai makhluk Tuhan Yang Maha Esa. ${ }^{1}$

Indonesia merupakan Negara yang terus-menerus berupaya menyempurnakan sistem pendidikan, memperbarui berbagai kebijakan dan perundang-undangan sistem pendidikan nasional. Hal itu di lakukan agar pendidikan benar-benar mampu menjadi agen pembaharuan dan kemajuan bagi bangsa dan negaranya dengan tetap berlandaskan pada prinsip keseimbangan antara aspek jasmani dan rohani, aspek fisik-material dan mental-spiritual, sehingga setiap warga Negara memperoleh kesejahteraan lahir dan batin.

Arah dan tujuan pendidikan nasional kita, seperti yang diamanatkan oleh UUD 1945, adalah peningkatan iman dan taqwa serta pembinaan akhlak mulia para peserta didik yang dalam hal ini adalah seluruh warga Negara yang mengikuti proses pendidikan di Indonesia. Karena itu pendidikan yang membangun nilainilai moral atau karakter di kalangan peserta didik harus selalu mendapatkan perhatian. Pendidikan di tingkat dasar( SD dan SMP) merupakan wadah yang sangat penting untuk mempersiapkan sejak dini para generasi penerus yang nantinya akan menjadi pemimpin bangsa kita di masa mendatang.

Undang-undang Nomor 20 Tahun 2003 tentang sistem pendidikan nasional pada pasal 3, menyebutkan bahwa pendidikan nasional

1 Abdul Majid, Dian Andayani, Pendidikan Agama Agama Islam Berbasis Kompetensi. Bandung: PT Remaja Rosda Karya. 2004. Hlm. 43. berfungsi mengembangkan kemampuan dan membentuk karakter serta peradaban bangsa yang bermartabat dalam rangka mencerdaskan kehidupan bangsa. Dan pendidikan nasional bertujuan untuk berkembang potensi peserta didik agar menjadi manusia yang beriman dan bertaqwa kepada Tuhan Yang Maha Esa, berakhlak mulia, sehat, berilmu, cakap, kreaktif, mamdiri dan menjadi warga Negara yang demokrasi serta bertanggung jawab. ${ }^{2}$

Berdasarkan fungsi dan tujuan pendidikan nasional, jelas bahwa pendidikan di setiap jenjang harusdiselenggarakan secara sistematis guna mencapai tujuan tersebut. Hal tersebut berkaitan dengan pembentukan karakter peserta didik sehingga mampu bersaing, beretika, bermoral, sopan santun dan berinteraksi dengan masyarakat. Karakter merupakan nilai-nilai perilaku manusia yang berhubungan dengan Tuhan Yang Maha Esa, diri sendiri, sesama manusia, lingkungan, dan kebanggaan yang terwujud dalam pikiran, sikap, perasaan, perkataan, dan perbuatan berdasarkan norma-norma agama, hukum, tata karma, dan adat istiadat.

\section{PEMBAHASAN}

\section{A. Pendidikan karakter}

Pendidikan karakter adalah suatu sistem penanaman nilai-nilai karakter kepada warga sekolah yang meliputi komponen pengetahuan, kesadaran atau kemauan, dan tindakan untuk melaksanakan nilai-nilai tersebut baik terhadap Tuhan Yang Maha Esa, diri sendiri, sesama, lingkungan, maupun kebangsaan sehingga menjadi manusia insan kamil. ${ }^{3}$ Pendidikan

2 Undang-undang Nomor 20 Tahun 2003 Tentang Sistem Pendidikan Nasional

3 Darma Kusuma, dkk. Pendidikan Karakter: 
karakter juga termasuk dalam materi yang harus diajarkan dan dikuasai serta direalisasikan oleh peserta didik dalam kehidupan seharihari. Permasalahannya, pendidikan karakter di sekolah selama ini baru menyentuh pada tingkatan pengenalan norma atau nilai-nilai dan belum pada tingkatan internalisasi dan tingkatan nyata dalam kehidupan sehari-hari di masyarakat. Padahal pendidikan karakter seharusnya membawa peserta didik ke pengenalan nilai secara kognitif, penghayatan nilai secara efektif dan akhirnya ke pengamalan nilai secara nyata.

Hal tersebut senada dengan Ratna Megawangi yang menengarai perlunya metode $4 \mathrm{M}$ dalam pendidikan karakter, yaitu mengetahui, mencintai, menginginkan dan mengerjakan ( knowing the good, loving the good, desiring the good and acting the good) kebaikan secara silmutan dan bersinambungan. Metode ini menunjukkan bahwa karakter adalah sesuatu yang dikerjakan berdasarkan kesadaran yang utuh. Sedangkan kesadaran utuh itu adalah sesuatu yang diketahui secara sadar, dicintainya dan diinginkan. Dari kesadaran utuh ini, barulah tindakan dapat menghasilkan karakter yang utuh pula. ${ }^{4}$

Berdasarkan penelitian di Harvard University Amerika Serikat, ternyata kesuksesan seseorang tidak ditentukan semata-mata oleh pengetahuan dan kemampuan teknis ( hard skill) saja, tetapi lebih oleh kemampuan mengelola diri dan orang lain ( soft skill). Penelitian ini mengungkapkan kesuksesan hanya ditentukan sekitar 20 persen oleh hard skill dan sisanya 80

Kajian Teori dan Praktek di Sekolah. Bandung; Remaja Rosda Karya. hlm. 3.

4Zakiyah Daradjat, Metodek Khusus Pengajaran Agama Islam, Jakarta: Bumi Aksara 2001. Hlm. 12. persen oleh soft skill. Bahkan orang-orang yang tersukses di dunia bisa berhasil dikarenakan lebih banyak didukung kemampuan soft skill daripada hard skill. Hal ini mengisyaratkan bahwa mutu pendidikan karakter peserta didik sangat penting untuk ditingkatkan. Soft skill ini merupakan bagian karakter yang harus dibentuk melalui pendidikan mulai tingkat pendidikan anak usia dini ( PAUD) sampai dengan perguruan tinggi.

Kementrian pendidikan Nasional telah mengembangkan grand design pendidikan karakter untuk setiap jalur, jenjang, dan jenis satuan pendidikan. Grand design ini menjadi rujukan konseptual dan operasional pengembangan, pelaksanaan dan penilaian pada setiap jalur dan jenjang pendidikan. Grand design pendidikan karakter nasional menyebutkan bahwa konfigurasi karakter dalam konteks totalitas proses psikologis dan sosialkultural tersebut dikelompokkan dalam olah hati ( spiritual and emotional development), olah pikir ( intellectual development), olah raga dan kinestetik ( Physical and kinesthetic development), olah rasa dan karsa ( affective and creativity development). ${ }^{5}$

Menurut Raharjo memaknai pendidikan karakter sebagai suatu proses pendidikan secara holistis yang menghubungkan dimensi moral dengan ranah sosial dalam kehidupan peserta didik sebagai pondasi bagi terbentuk genarasi yang berkualitas yang mampu hidup mandiri dan memiliki prinsip suatu kebenaran yang dapat dipertanggung jawabkan. ${ }^{6}$

5 Ari Ginanjar Agustian, Rahasia Sukses Membangun Kecerdasan Emosional dan Spiritual ESQ. Jakarta: Arga. 2001. Hlm.13.

6 Raharjo, Pendidikan Karakter Sebagai Upaya Menciptakan Akhlak Mulia, dalam Jurnal Pendidikan dan Kebudayaan, Jakarta: Balitbang Kementrian 
Menurut

suyanto mendefinisikan

Selamat

karakter sebagai cara berpikir dan berperilaku yang menjadi ciri khas tiap individu untuk hidup dan bekerja sama, baik dalam lingkup keluarga, masyarakat, bangsa, maupun negara. Individu yang berkarakter baik adalah individu yang bisa membuat keputusan dan siap mempertanggungjawabkan tiap akibat dari keputusan yang ia buat. ${ }^{7}$ Hermawan kertajaya juga mendefinisikan pendidikan karakter adalah ciri khas yang dimiliki oleh suatu benda atau individu. Ciri khas tersebut adalah asli dan mengakar pada kepribadian benda atau individu tersebut, serta merupakan "mesin" yang mendorong bagaimana seorang bertindak, bersikap, berucap, dan merespon sesuatu. ${ }^{8}$

\section{B. Pengertian iman dan taqwa}

Kata iman dari bahasa arab yaitu amana artinya aman. Maksudnya orang yang beriman selalu memiliki perasaan aman karena yakin selalu dilindungi oleh Allah SWT. Dalam kaitan inilah iman terkait dengan aqidah. Aqidah itu berasal dari bahasa Arab" aqad" artinya ikatan. Maksudnya ikatan hati dengan Allah. Definisi iman adalah keyakinan penuh yang dibenarkan oleh hati, diucapkan oleh lidah dan diwujudkan oleh amal perbuatan.

Sistematika dan implementasi arkanul iman adalah sebagai berikut:

1. Beriman kepada Allah

Pendidikan Nasional,Vol. 16 No. 3 Mei 2010).

7 Selamat suyanto, Strategi Pendidikan Anak, Yogyakarta : Hikayat, 2009. Hlm. 45.

8 Hermawan kertajaya, kalau keunikan ditunjukkan, Bandung: Gramedia,2010. Hlm. 15. a. Keyakinan dan ketundukan hanya kepada Allah.

b. Allah SWT yang menentukan segala sesuatu tanpa ada campur tangan kekuasaan lain.

c. Dari Allah SWT alam ini dan Allah SWT pula yang menentukan batasannya.

2. Beriman kepada Malaikat.

a. Meyakini ada makhluk gaibyang bernama malaikat dengan tugas yang telah di gariskan Allah SWT.

b. Kehadiran malaikat sangat berkaitan dengan kelangsungan hidup manusia atau alam ini.

3. Beriman kepada Rasul Allah.

a. Meyakini pesuruh Allah di atas bumi ini hanya Rasul Allah yang di bimbing oleh wahyu.

b. Menteladani dan mengikuti petunjuknya yang sangat benar dan sangat pasti.

4. Beriman kepada kitab Allah.

a. Meyakini keberadaan wahyu atau firman Allah yang ditulis dalam kitab agama samawi.

b. Kitab agama samawi kebenaran isi dan tulisannya itu adalah mutlak dari Allah.

5. Beriman kepada hari kiamat

a. Meyakini dibalik kehidupan fana( dunia) ini ada lagi kehidupan yang abadi dan kekal.

b. Adanya pertangung jawaban dari manusia kepada Allah.

c. Adanya pembagian tempat dan kedudukan bagi manusia 
nantinya yang sesuai dengan ibadah dan amalannya.

6. Beriman kepada qada dan qadar.

a. Dalam kehidupan ini tetap ada campur tangan Allah SWT ( genggaman kekuasaan).

b. Usaha dan perjuangan manusia sangat bersinergi dengan kasih sanyang Allah SWT.

Taqwa berarti hati-hati, mawas diri dan waspada. Menurut H.A. Salim dalam "Dienul Islam “ yang dituliskan oleh H.Nasruddin Rajak, disebutkan bahwa taqwa lebih tepat disalin dengan kata " ingat" dengan makna: awas, hatihati yaitu menjaga diri, memelihara keselamatan diri, yang dapat diusahakan dengan melakukan yang baik dan yang benar, menjauhi yang jahat dan salah. Jadi pengertian taqwa secara umum ialah sikap mental orang-orang mukmin dari kepatuhannya dalam melaksanakan perintah-perintah Allah SWT serta menjauhi larangan-laranganNya atas dasar kecintaan semata. Taqwa merupakan nilai yang mendasardan sangat mulia yang harus dimiliki oleh seorang Muslim dikarenakan:

1. Ukuran jauh dekatnya seseorang dengan Allah SWT. Orang yang paling mulia disisi Allah adalah orang bertaqwa (Al-Hujarat:13).

2. Merupakan bekal yang paling baik( Al-Baqarah:197).

3. Pakaian yang paling baik yang harus dipakai oleh manusia ( Al-A'raf:26)

4. Kekasih atau disayangi Allah SWT ( Yunus:62-63).
5. Amalan orang yang taqwa diterima Allah SWT( Al-Maidah: 27).

Iman dan taqwa adalah dua unsur pokok bagi pemeluk Agama. Keduanya merupakan elemen yang penting dalam kehidupan manusia dan sangat erat hubungannya dalam menentukan nasib hidupnya serta memiliki fungsi yang urgen, ${ }^{9}$ khususnya filsafat agama yang membahas masalah agama dari segi filsafat. Filsafat agama dalam pandangan berbagai filosofi bukanlah pembahasan filsafat secara bebas, tetapi ia membahas agama dari segi aspek filsafat dengan titik tolak tertentu. Agama itu bermacam-macam pedoman dan landasannya, oleh karena itu maka sudah barang tentu landasan yang dipergunakan sebagai titik tolak pembahasan tulisan ini adalah ajaran Islam.

Landasan berfilsafat adalah akal bukan wahyu, oleh karena itu dalam sejarah filsafat terdapat filosof yang beriman dan ada pula filosof yang kufur yang hanya percaya pada pengetahuan indra yang didukung oleh akal, terutama filosofi yang beraliran materialisme. Sebenarnya antara berfikir filosofis dan berfikir religious mempunyai titik mulai yang sama, keduanya mulai dengan percaya. Dalam filsafat di mulai dengan percaya pada kemampuan akal, sedangkan dalam agama dimulai dengan percaya pada ketetapan wahyu. Menurut agama Islam diartikan secara sederhana adalah kepercayaan yang memunculkan ketaqwaan, sedangkan dalam filsafat agama, iman tersebut dipahami secara radikal dan ketaqwaan dipahami sebagai

9 Ami Ince, Signifikansi Pendidikan Iman dan Taqwa Bagi Siswa di Era Globalisasi, Jurnal Iqra, Ilmu Kependidikan dan Keislaman, Vol. 4, No. 1, 2008. Hlm.29. 
konsep etika. ${ }^{10}$

Indikator orang beriman dan bertaqwa

a. Indikator orang beriman antara lain:

1. Senantiasa hatinya bergetar apabila membaca, mendengar ayat-ayat suci Al-Qur'an( QS. Al-Anfal:2).

2. Mendirikan shalat dan menafkahkan sebahagiaan rezeki yang diberikan oleh Allah SWT( QS. Al-Anfal:3).

3. Taat kepada Allah dan RasulNya( QS. Al-Anfal:24).

4. Beramal dan berdakwah dengan penuh kesabaran( QS. Al'Ashr:3).

Indikator orang yang bertaqwa antara lain:

1. Memelihara diri dari hal yang menjerumuskan ke neraka. Dalam Al-Qur'an disebut pada surat (AliImran:131).

2. Selalu menuju kepada maghfirah ( ampunan Allah SWT).( QS. AlImran:133).

3. Apabila berbuat keji, segera mengingat Allah dan memohon ampuna-Nya ( QS.Al-Imran:135).

Kemudian indikator iman dan taqwa dapat di rincikan sebagai berikut:

1. Aspek keyakinan yang mencerminkan nilai-nilai Islam.

2. Aspek ucapan yang mencerminkan nilai-nilai Islam.

3. Aspek perbuatan yang mencerminkan nilai-nilai Islam.

10 D.,Ahmad Marimba, Pengantar Flisafat Pendidikan Islam. Bandung: PT. Al-Maarif. 1981. Hlm. 23.

6 | BIDAYAH: Volume 11, No. 1, Juni 2020
Mentalitas iman dan taqwa yang harus ditanamkan antara lain:

a. Tawadlu': rendah hati atau tidak sombong.

b. Qonaah: merasa cukup dengan yang dititipkan Allah.

c. Wara: menjauhi yang haram dan subbut.

d. Yakin: optimisme. ${ }^{11}$

\section{Peran pendidik dalam pelaksanaan pendidikan karakter berbasis iman dan} taqwa

Dalam tataran operasional, maka pengejawantahan cita-cita pembangunan manusia Indonesia yang beriman dan bertaqwa melalui pendidikan karakter pada pundak pendidik. Dengan demikian, komunitas pendidik mempunyai peran dan kedudukan strategis dalam pembangunan nasional khususnyadalam mewujudkan tujuanb pendidikan nasional. Undang-undang Nomor 14 Tahun 2005 tentang guru dan dosen mendefinisikan guru sebagai pendidik professional dengan tugas utama mendidik, mengajar, membimbing, mengarahkan, melatih, menilai, dan mengevaluasi peserta didik. ${ }^{12}$

> Terdapat beberapa sasaran utama yang perlu menjadi perhatikan sebagai target dalam peningkatan nilai iman dan taqwa bagi pendidik sebagai berikut:

a. Pendidik dapat memahami konsep tauhid yang benar.

b. Pendidik dapat memahami pedoman

11 Zakiyah Daradjat, Ilmu Pendidikan Islam. Jakarta: Bumi Aksara 2000. Hlm. 38.

12 Undang-undang Nomor 14 Tahun 2005 Tentang Guru dan Dosen. 
hidup hakiki secara kaffah.

c. Pendidik dapat memahami Hadist secara benar dan menyeluruh.

d. Terlahirnya semangat silahturahmi dari para pendidik kepada kaum ilmuwan.

e. Lahirnya kebiasaan untuk berdiskusi nilai-nilai agama di lingkungan tempat pendidik bekerja.

f. Lahirnya sikap yang santun dalam berinteraksi dengan lingkungannya.

g. Lahirnya kebiasaan yang konsisten untuk beramal shaleh.

h. Meningkatkan tanggungjawab dalam bekerja. ${ }^{13}$

\section{Iman dan taqwa dalam perspektif perundang-undangan}

Perubahan Undang-Undang sistem pendidikan nasional dari Undang-Undang Nomor 2 Tahun 1989 kepada Undang-Undang Nomor 20 tahun 2003 diantaranya dikarenakan tidak memadai laginya Undang-Undang yang pertama dan disempurnakan agar sesuai dengan amanat perubahan Undang-Undang Dasar Negara Republik Indonesia Tahun 1945. Perubahan ini secara langsung juga berimplikasi terhadap model pendidikan secara nasional, terutama nilai baik di lingkungan pendidikan formal maupun pendidikan non formal( PLS). Minimal terdapat empat factor yang mendukung pendidikan nilai dalam proses pembelajaran berdasarkan Undang-Undang Sistem Pendidikan Nasional( UUSPN) Nomor 20 Tahun 2003 sebagai berikut:

13 Direktorat Jendral Pendidikan Dasar dan Menengah. Bahan Dasar Peningkatan Guru Agama. Jakarta: Departemen Pendidikan Kebudayaan. Hlm. 2022.
1. (UUSPN) Nomor 20 Tahun 2003 yang bercirikan desentralistik menunjukkan bahwa pengembangan nilai-nilai kemanusiaan terutama yang dikembangkan melalui demokratisasi pendidikan menjadi hal utama.

2. Tujuan pendidikan nasional yang utama menekankan pada aspek keimanan dan ketaqwaan.

3. Kurikulum berbasis kompetensi( KBK) pada UUSPN No. 20 Tahun 2003 menandakan bahwa nilainilai kehidupan peserta didik perlu dikembangkan sesuai dengan kebutuhan dan kemampuan belajar mereka.

4. Perhatian UUSPN No.20 Tahun 2003 terhadap pendidikan anak usia dini( PAUD) memiliki misi nilai yang amat penting bagi perkembangan anak.

\section{E. Iman dan taqwa dalam perspektif kecerdasan emosional ( EQ)}

Akar kata emotion adalah movere, kata latin yang berarti " bergerak", ditambah awalan "e" memberi arti " bergerak menjauh". Kata emosi merujuk kepada suatu perasaan dan pikiran-pikiran yang menyertainya, keadaan psikologis dan biologis dan sederet( dorongan) untuk beraksi. The Orford English Dictionary mendefinisikan emosi sebagai "setiap agitasi atau gangguan dari jiwa, perasaan, kemarahan, nafsu ( keinginan besar), setiap keadaan jiwa yang penuh semangat atau gairah( excited)". Padanan istilah emosi yang mendekati kesesuaian dalam Al-Qur'an mungkin adalah Nafs ( dalam bahasa Indonesia disebut nafsu atau hawa nafsu). Namun kata nafs sendiri dalam Al-Qur'an juga ada yang bermakna 
nyawa atau diri atau pribadi, dalam surat AlImran:158;

Tiap-tiap yang berjiwa akan merasakan mati. Dan sesungguhnya pada harikiamat sajalah disempurnakan pahalamu. Barang siapa dijauhkan dari neraka dan dimasukkan ke dalam syurga, maka sungguh ia telah beruntung. Kehidupan dunia itu tidak lain hanyalah kesenangan yang memperdayakan.

Kecerdasan emosional erat hubungannya dengan perasaan manusia. Emosi menuntut kita menghadapi saat-saat kritis dan tugas-tugas yang terlampau riskan bila hanya diserahkan kepada otak. Perasaan bisa dipengaruhi oleh beberapa factor diantaranya sugesti, kelelahan, perhatian, intelegensi sehingga ikut mewarnai emosi. Istilah " kecerdasan emosional” pertama kali disampaikan pada tahun 1990 oleh ahli psikologi Pieter Salovey dari Universitas Harvard dan John Mayer dari Universitas New Hampshire, keduanya menerangkan akan adanya kualitas-kualitas yang penting bagi keberhasilan antara lain: empati, mengungkapkan dan memahami perasaan, mengendalikan amarah, kemandirian, kemampuan menyesuaikan diri, disukai, kemampuan memecahkan masalah antar pribadi, ketekunan, kesetia-kawanan, keramahan dan sikap hormat.

Salovey dan Meyer sendiri mengatakan kecerdasan emosional sebagai himpunan bagian dari kecerdasan sosial yang melibatkan kemampuan memantau perasaan dan emosi baik pada diri sendiri maupun pada orang lain, memilah-milah semuanya dan menggunakan informasi ini untuk membimbing pikiran dan tindakan. Menurut Seto Mulyadi, kecerdasan emosional adalah kemampuan mengenali emosi orang lain dan kemampuan membina hubngan. Kecerdasan emosional adalah kemampuan mengenali emosi diri, merupakan kemampuan seseorang dalam mengenali perasaannya sendiri sewaktu perasaan atau emosi itu muncul dan ia mampu mengenali emosinya sendiri apabila ia memiliki kepekaan yang tinggi atas perasaan mereka yang sesungguhnya dan kemudian mengambil keputusan-keputusan secara mantap.

Secara sederhana Ary Ginanjar mengartikan kecerdasan emosional adalah kemampuan merasakan dan cara meningkatkan ini adalah dengan cara mempraktekkannya. ${ }^{14}$ Sedangkan menurut Patricia Patton memberi makna kecerdasan emosional sebagai kekuatan di balik singgasana kemampuan intelektual. Ia merupakan dasar-dasar pembentukan emosi yang mencakup tentang kemampuankemampuan untuk menunda kepuasan dan mengendalikan dorongan-dorongan, tetap optimis jika berhadapan dengan kemalangan dan ketidakpastian, menyalurkan emosi-emosi yang kuat secara efektif, mampu memotivasi dan menjaga semangat disiplin diri dalam usaha mencapai tujuan-tujuan, menangani kelemahankelemahan pribadi, dan menunjukkan rasa empati kepada orang lain. ${ }^{15}$

$>$ Konsep kecerdasan emosional terdiri dari:

1. Kemampuan mengenali emosi diri.

2. Kemampuan mengelola emosi diri.

14 Ary Ginanjar Agustian, Rahasia SuksesMembangun Kecerdasan Emosi dan spiritual ESQ, Jakarta: Arga. 2001.Hlm. 54.

15 Patricia Patton, Emotinal Intelligence (EQ), Perkembangan Sukses Lebih Bermakna. Mitra Media. 2002.hlm.54. 
3. Kemampuan memotivasi diri.

4. Kemampuan mengenali emosi orang lain.

Menurut Goleman, seorang yang mengalami kemerosotan emosi akan mempunyai perilaku sebagai berikut:

a. Menarik diri dari pergaulan atau masalah sosial, lebih suka menyendiri, bersikap sembunyi-sembunyi, banyak bermuram durja, kurang bersemangat, merasa tidak bahagia, terlampau bergantung.

b. Cemas dan depresi, menyendiri, sering takut dan cemas, ingin sempurna, merasa tidak dicintai, merasa gugup atau sedih dan depresi.

c. Memiliki masalah dalam perhatian atau berfikir, tidak mampu memusatkan perhatian atau duduk tenang, melamun, bertindak tanpa berfikir, bersikap terlalu tegang untuk berkonsentrasi, sering mendapat nilai buruk disekolah, tidak mampu membuat pikiran menjadi tenang.

d. Nakal atau agresif, bergaul dengan anak-anak yang bermasalah, bohong dan menipu, sering bertengkar, bersikap kasar terhadap orang lain, menuntut perhatian, merusak milik orang lain, membandel di sekolah dan di rumah, keras kepala dan suasana hatinya sering berubah-ubah, terlalu banyak berbicara, sering mengolok-olok, bertemperamen penasaran.

Ada banyak keuntungan bila sesorang mempunyai kecerdasan emosi yang baik diantaranya:

1. Kecerdasan emosional mampu menjadi alat untuk pengendalian diri sehingga seseorang tidak terjerumus ke dalam tindakan bodoh yang merugikan diri sendiri dan orang lain.

2. Kecerdasan emosional bisa diimplementasikan sebagai cara yang sangat baik untuk memusatkan atau membesarkan ide, konsep, atau bahkan sebuah produk, dengan pemahaman tentang diri, kecerdasan emosional juga menjadi cara terbaik dalam membangun lobby jaringan dan kerjasama.

3. Kecerdasan emosional adalah modal penting bagi seseorang untuk mengembangkan bakat kepemimpinan dalam bidang apapun juga. ${ }^{16}$

Menurut Daniel Goleman unsur-unsur utama dalam kecerdasan emosional adalah sebagai berikut:

a. Kesadaran diri: mengamati diri sendiri dan mengenali perasaan diri sendiri, menghimpun kosa kata untuk perasaan, mengetahui hubungan antara pikiran, perasaan dan reaksi.

b. Pengambilan keputusan pribadi: mencermati tindakan-tindakan diri sendiri dan mengetahui akibatnya, mengetahui apa yang menguasai sebuah keputusan, pikiran atau perasaan, menerapkan pemahaman ini ke masalah seperti seks dan obat

16 Daniel Goleman,Emotional Intellingence, Mengapa EQ Lebih Penting Daripada IQ. Jakarta: PT Gramedia Pustaka Utama. 2003. Hlm. 58. 
terlarang.

c. Mengelola perasaan: memantau "pembicaraan sendiri” untuk menangkap pesan negatif seperti ejekan tersembunyi, menyadari apa yang di balik suatu perasaan (misalnya sakit hati yang mendorong amarah), menemukan cara untuk menangani rasa takut dan cemas, amarah dan kesedihan.

d. Menanganistres: mrmpelajari pentingnya berolahraga, perenungan yang terarah, metode relaksasi.

e. Empati: memahami perasaan dan masalah orang lain dan berfikir dengan sudut pandang mereka, menghargai perbedaan perasaan orang mengenai berbagai hal.

f. Komunikasi: berbicara mengenai perasaan secara efektif, menjadi pendengar dan penanya yang baik, membedakan antara apa yang dilakukan atau yang dikatakan seseorang dengan reaksi atau penilaian diri sendiri tentang hal itu, mengirimkan pesan" aku" dan bukannya mengumpat.

g. Membuka diri: menghargai keterbukaan dan membina kepercayaan dalam suatu hubungan, mengetahui kapan situasinya aman untuk mengambil resiko membicarakan tentang perasaan diri sendiri.

h. Pemahaman: mengidentifikasi pola dalam kehidupan emosional dirisendiri dan reksinya, mengenali pola serupa pada orang lain. i. Menerima diri sendiri: merasa bangga dan memandang diri sendiri dari sisi positif, mengenali kekuatan dan kelemahan diri sendiri, mampu untuk mempertawakan diri sendiri.

j. Tanggung jawab pribadi: rela memikul tanggung jawab, mengenali akibat dari keputusan dan tindakan diri sendiri, menerima perasaan dan suasana hati diri sendiri, menindaklanjuti komitmen ( misalnya berniat untuk belajar).

k. Ketegasan: mengungkapkan keprihatinan dan perasaan diri sendiri tanpa rasa marah atau berdiam diri.

I. Dinamika kelompok: mau bekerja sama, mengetahui kapan dan bagaimana memimpin, kapan mengikuti.

m. Menyesuaikan konflik: bagaimana berkelahi secara jujur dengan anakanak lain, orang tua, dengan para peserta didik, contoh menang untuk merunding kompromi.

Berdasarkan unsur-unsur utama dalam kecerdasan emosional di atas dapat diambil benang merah bahwa titik pokok kecerdasan emosional terletak pada pengarahan perasaan atau pengendalian perasaan ( diri, jiwa, pribadi) dalam rangka memadukan emosi dan intelektual menjadi pribadi yang baik dan cerdas.

\section{F. Iman dan taqwa perspektif kecerdasan spiritual ( SQ)}

Menurut Danah Zohar dan Ian Marsall, orangyangpertamakalimengeluarkanidetentang 
konsep kecerdasan spiritual, mendefinisikan kecerdasan spiritual adalah kecerdasan untuk menghadapi dan memecahkan persoalan makna dan nilai, kecerdasan yang memberikan makna, yang melakukan kontektualisasi dan bersifat transformatif. Mereka mengatakan kecerdasan untuk menempatkan perilaku dan hidup kita dalam konteks makna yang lebih luas dan kaya. Dan kecerdasan itu untuk menilai bahwa tindakan atau jalan hidup sesorang lebih bermakna dibandingkan dengan yang lain. Danah Zohar juga mengatakan bahwa kecerdasan yang bertumpu pada bagian dalam individu yang berhubungan dengan kearifan di luar ego, atau jiwa sadar. ${ }^{17}$ Hal utama dalam kecerdasan spiritual adalah pengenalan akan kesejahteraan diri manusia.

Kecerdasan spiritual bukan sebuah ajaran teologis, kecerdasan ini secara tidak langsung berkaitan dengan agama. Kecerdasan spiritual itu mengarahkan manusia pada pencarian hakikat kemanusiaan. Hakikat manusia dapat ditemukan dalam perjumpaan atau saat berkomunikasi antara manusia dengan Allah swt( misalnya pada saat shalat). Oleh karena itu, ada yang berpandangan bahwa kecerdasan manusia spiritual ( SQ) adalah kecerdasan manusia yang digunakan untuk berhubungan dengan Tuhan. Asumsinya adalah jika seseorang hubungan dengan Tuhannya baik, maka bisa dipastikan hubungan dengan sesama manusia pun akan baik.

Kecerdasan spiritual ( SQ) itu menurut penelitian-penelitian di bidang neurology, punya tempat yang khusus dalam otak. Ada bagian dari otak kita yang memiliki

17 Danar Zohar, Ian Massal, Kecerdasan Spiritual, Bandung: Mizan. 2001. Hlm. 62. kemampuan untuk mengalami pengalaman spiritual, misalnya untuk memahami Tuhan dan memahami sifat-sifat Tuhan. Maksudnya adalah menyadari kehadiran Tuhan disekitar kita dan untuk memberi makna dalam kehidupan. Orang yang cerdas secara spiritual di antaranya bisa dilihat ciri-cirinya antara lain yaitu, bisa memberi makna dalam kehidupannya, senang berbuat baik, senang menolong orang lain, telah menemukan tujuan hidupnya, dia merasa memikul misi yang mulia, dia merasa dilihat oleh Tuhannya.

Menurut Danah Zohar dan Mashall, tanda-tanda dari kecerdasan spiritual yang telah berkembang dengan baik adalah sebagai berikut:

1. Kemampuan bersikap fleksibel adaptif secara spontan dan aktif).

2. Kemampuan untuk menghadapi dan memanfaatkan penderitaan untuk menghadapi dan melampaui rasa sakit.

3. Kualitas hidup yang diilhami oleh kualitas visi dan nilai.

4. Keengganan untuk menyebabkan kerugian yang tidak perlu.

5. Kecendrungan untuk melihat keterkaitan antara berbagai hal ( berpandangan holistik).

6. Kecendrungan nyata untuk bertanya mengapa atau bagaimana untuk mencari jawaban yang mendasar.

\section{Bab III Kesimpulan}

1. Pendidikan karakter adalah suatu sistem penanaman nilai-nilai karakter kepada warga sekolah yang meliputi komponen pengetahuan, kesadaran atau kemauan, 
dan tindakan untuk melaksanakan nilai-nilai tersebut baik terhadap Tuhan Yang Maha Esa, diri sendiri, sesama, lingkungan, maupun kebangsaan sehingga menjadi manusia insan kamil.

2. Kata iman dari bahasa arab yaitu amana artinya aman. Maksudnya orang yang beriman selalu memiliki perasaan aman karena yakin selalu dilindungi oleh Allah SWT. Dalam kaitan inilah iman terkait dengan aqidah. Aqidah itu berasal dari bahasa Arab" aqad" artinya ikatan. Maksudnya ikatan hati dengan Allah. Definisi iman adalah keyakinan penuh yang dibenarkan oleh hati, diucapkan oleh lidah dan diwujudkan oleh amal perbuatan.

3. Taqwa berarti hati-hati, mawas diri dan waspada. Menurut H.A. Salim dalam "Dienul Islam " yang dituliskan oleh H.Nasruddin Rajak, disebutkan bahwa taqwa lebih tepat disalin dengan kata " ingat" dengan makna: awas, hatihati yaitu menjaga diri, memelihara keselamatan diri, yang dapat diusahakan dengan melakukan yang baik dan yang benar, menjauhi yang jahat dan salah. Jadi pengertian taqwa secara umum ialah sikap mental orang-orang mukmin dari kepatuhannya dalam melaksanakan perintah-perintah Allah SWT serta menjauhi larangan-laranganNya atas dasar kecintaan semata.

4. Kecerdasan emosional erathubungannya dengan perasaan manusia. Emosi menuntut kita menghadapi saat-saat kritis dan tugas-tugas yang terlampau riskan bila hanya diserahkan kepada otak. Perasaan bisa dipengaruhi oleh beberapa factor diantaranya sugesti, kelelahan, perhatian, intelegensi sehingga ikut mewarnai emosi. Istilah " kecerdasan emosional" pertama kali disampaikan pada tahun 1990 oleh ahli psikologi Pieter Salovey dari Universitas Harvard dan John Mayer dari Universitas New Hampshire, keduanya menerangkan akan adanya kualitaskualitas yang penting bagi keberhasilan antara lain: empati, mengungkapkan dan memahami perasaan, mengendalikan amarah, kemandirian, kemampuan menyesuaikan diri, disukai, kemampuan memecahkan masalah antar pribadi, ketekunan, kesetia-kawanan, keramahan dan sikap hormat.

5. Menurut Danah Zohar dan Ian Marsall, orang yang pertama kali mengeluarkan ide tentang konsep kecerdasan spiritual, mendefinisikan kecerdasan spiritual adalah kecerdasan untuk menghadapi dan memecahkan persoalan makna dan nilai, kecerdasan yang memberikan makna, yang melakukan kontektualisasi dan bersifat transformatif. Mereka mengatakan kecerdasan untuk menempatkan perilaku dan hidup kita dalam konteks makna yang lebih luas dan kaya. Dan kecerdasan itu untuk menilai bahwa tindakan atau jalan hidup sesorang lebih bermakna dibandingkan dengan yang lain. Danah Zohar juga mengatakan bahwa kecerdasan yang bertumpu pada bagian dalam individu yang berhubungan dengan kearifan di luar ego, atau jiwa sadar. 


\section{DAFTAR PUSTAKA}

Abdul Majid, Dian Andayani, Pendidikan Agama Agama Islam Berbasis Kompetensi. Bandung: PT Remaja Rosda Karya. 2004.

Ami Ince, Signifikansi Pendidikan Iman dan Taqwa Bagi Siswa di Era Globalisasi, Jurnal Iqra, Ilmu Kependidikan dan Keislaman, Vol. 4, No. 1, 2008.

Ary Ginanjar Agustian, Rahasia SuksesMembangun Kecerdasan Emosi dan spiritual ESQ, Jakarta: Arga. 2001.

Ary Ginanjar Agustian, Rahasia Sukses

Membangun Kecerdasan Emosional dan Spiritual ESQ. Jakarta: Arga. 2001.

D.,Ahmad Marimba, Pengantar Flisafat Pendidikan Islam. Bandung: PT. Al-Maarif. 1981.

Danar Zohar, Ian Massal, Kecerdasan Spiritual, Bandung: Mizan. 2001.

Daniel

Goleman,Emotional

Intellingence, Mengapa EQ Lebih Penting

Daripada IQ. Jakarta: PT Gramedia Pustaka Utama. 2003.

Darma Kusuma, dkk. Pendidikan Pengajaran Agama Islam, Jakarta: Bumi Aksara Karakter: Kajian Teori dan Praktek di Sekolah. 2001.
Bandung; Remaja Rosda Karya.

Direktorat Jendral Pendidikan Dasar dan Menengah. Bahan Dasar Peningkatan Guru Agama. Jakarta: Departemen Pendidikan Kebudayaan.

Hermawan kertajaya, kalau keunikan ditunjukkan, Bandung: Gramedia,2010.

Patricia Patton, Emotinal Intelligence( EQ), Perkembangan Sukses Lebih Bermakna. Mitra Media. 2002.

Raharjo, Pendidikan Karakter Sebagai Upaya Menciptakan Akhlak Mulia, dalam Jurnal Pendidikan dan Kebudayaan, Jakarta: Balitbang Kementrian Pendidikan Nasional,Vol. 16 No. 3 Mei 2010).

Selamat suyanto, Strategi Pendidikan Anak, Yogyakarta : Hikayat, 2009.

Undang-undang Nomor 14 Tahun 2005 Tentang Guru dan Dosen.

Undang-undang Nomor 20 Tahun 2003

Tentang Sistem Pendidikan Nasional

Zakiyah Daradjat, Ilmu Pendidikan Islam. Jakarta: Bumi Aksara 2000.

Zakiyah Daradjat, Metodek Khusus 
ISSN: 2085-2541

14 | BIDAYAH: Volume 11, No. 1, Juni 2020 